\title{
LEVEL II SCOUR ANALYSIS FOR BRIDGE 46 (BRIDTH00050046) on TOWN HIGHWAY 5, crossing the NORTH BRANCH OTTAUQUECHEE RIVER, BRIDGEWATER, VERMONT
}

U.S. Geological Survey Open-File Report 96-311

Prepared in cooperation with

VERMONT AGENCY OF TRANSPORTATION and

FEDERAL HIGHWAY ADMINISTRATION

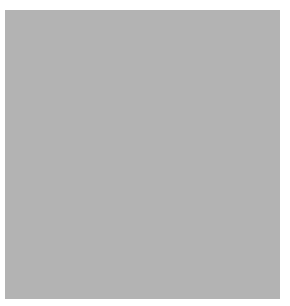


LEVEL II SCOUR ANALYSIS FOR

BRIDGE 46 (BRIDTH00050046) on

TOWN HIGHWAY 5, crossing the

NORTH BRANCH OTTAUQUECHEE RIVER,

BRIDGEWATER, VERMONT

By SCOTT A. OLSON and DONALD L. SONG

U.S. Geological Survey

Open-File Report 96-311

Prepared in cooperation with

VERMONT AGENCY OF TRANSPORTATION

and

FEDERAL HIGHWAY ADMINISTRATION 


\title{
U.S. DEPARTMENT OF THE INTERIOR BRUCE BABBITT, Secretary
}

\author{
U.S. GEOLOGICAL SURVEY \\ Gordon P. Eaton, Director
}

For additional information write to:

District Chief

U.S. Geological Survey 361 Commerce Way

Pembroke, NH 03275
Copies of this report may be purchased from:

U.S. Geological Survey Earth Science Information Center Open-File Reports Section Box 25286, MS 517 Federal Center

Denver, CO 80225 


\section{CONTENTS}

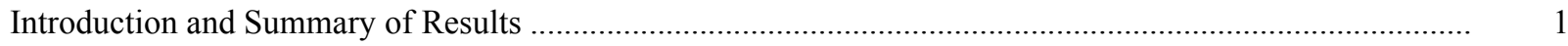

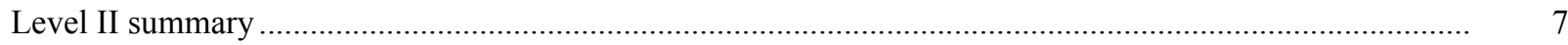

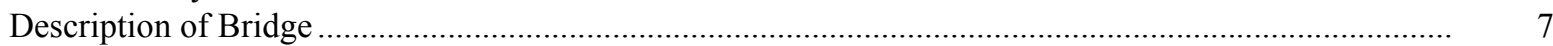

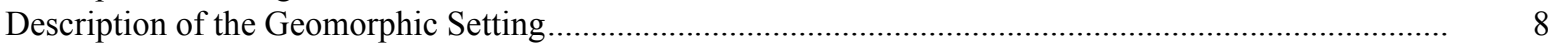

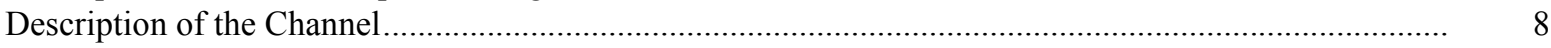

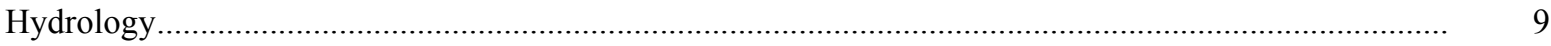

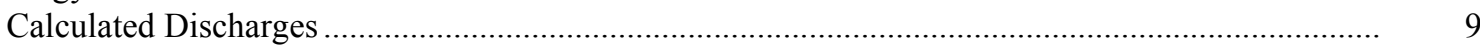

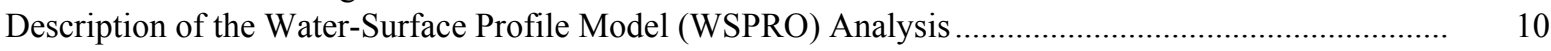

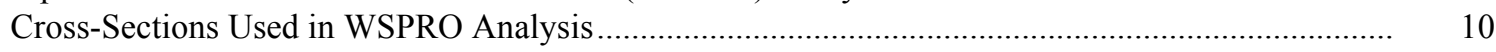

Data and Assumptions Used in WSPRO Model ...................................................................... 11

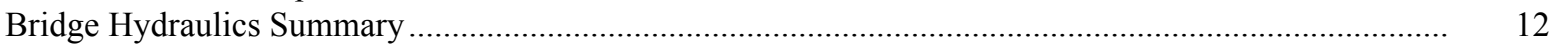

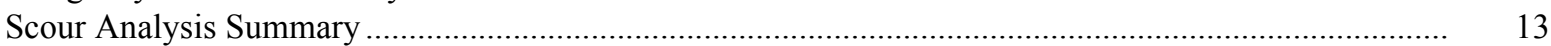

Special Conditions or Assumptions Made in Scour Analysis ...................................................... 13

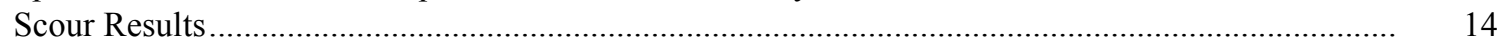

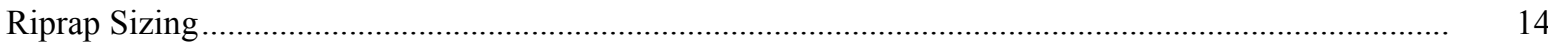

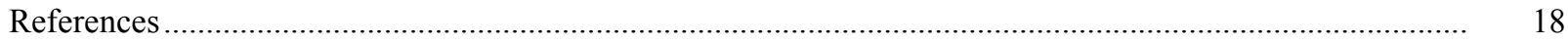

Appendixes:

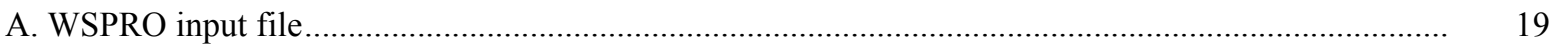

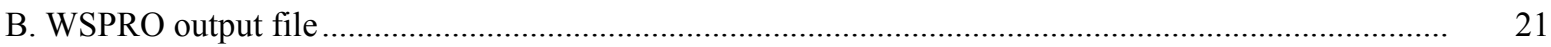

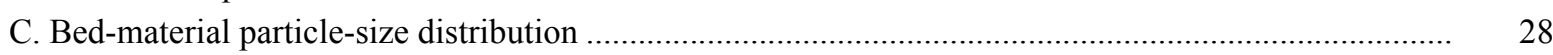

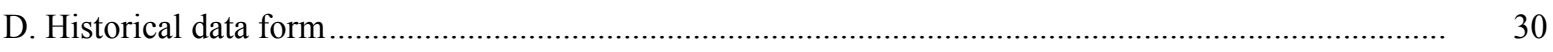

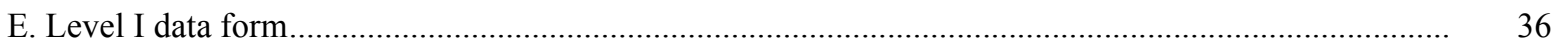

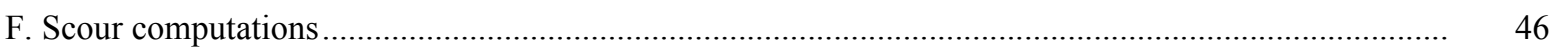

\section{FIGURES}

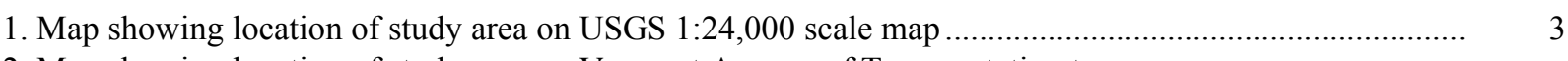

2. Map showing location of study area on Vermont Agency of Transportation town
highway map

3. Structure BRIDTH00050046 viewed from upstream (November 3, 1994)............................................ 5

4. Downstream channel viewed from structure BRIDTH00050046 (November 3, 1994)......................... 5

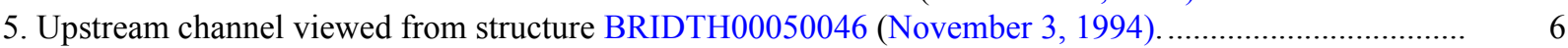

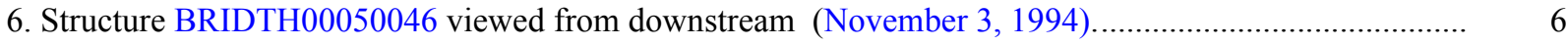

7. Water-surface profiles for the 100- and 500-year discharges at structure

BRIDTH00050046 on Town Highway 5, crossing the North Branch Ottauquechee River,

Bridgewater, Vermont.

8. Scour elevations for the 100- and 500-year discharges at structure

BRIDTH00050046 on Town Highway 5, crossing the North Branch Ottauquechee River,

Bridgewater, Vermont.

\section{TABLES}

1. Remaining footing/pile depth at abutments for the 100-year discharge at structure

BRIDTH00050046 on Town Highway 5, crossing the North Branch Ottauquechee River,

Bridgewater, Vermont

2. Remaining footing/pile depth at abutments for the 500-year discharge at structure

BRIDTH00050046 on Town Highway 5, crossing the North Branch Ottauquechee River,

Bridgewater, Vermont.

(1)

5

6

6




\begin{tabular}{|c|c|c|}
\hline Multiply & By & To obtain \\
\hline \multicolumn{3}{|c|}{ Length } \\
\hline inch (in.) & 25.4 & millimeter (mm) \\
\hline foot $(\mathrm{ft})$ & 0.3048 & meter $(\mathrm{m})$ \\
\hline mile (mi) & 1.609 & kilometer (km) \\
\hline \multicolumn{3}{|c|}{ Slope } \\
\hline foot per mile ( $\mathrm{ft} / \mathrm{mi})$ & 0.1894 & meter per kilometer $(\mathrm{m} / \mathrm{km})$ \\
\hline \multicolumn{3}{|c|}{ Area } \\
\hline square mile $\left(\mathrm{mi}^{2}\right)$ & 2.590 & square kilometer $\left(\mathrm{km}^{2}\right)$ \\
\hline \multicolumn{3}{|c|}{ Volume } \\
\hline cubic foot $\left(\mathrm{ft}^{3}\right)$ & $\begin{array}{l}0.02832 \\
\text { Velocity and Flow }\end{array}$ & cubic meter $\left(\mathrm{m}^{3}\right)$ \\
\hline foot per second (ft/s) & 0.3048 & meter per second $(\mathrm{m} / \mathrm{s})$ \\
\hline cubic foot per second $\left(\mathrm{ft}^{3} / \mathrm{s}\right)$ & 0.02832 & cubic meter per second $\left(\mathrm{m}^{3} / \mathrm{s}\right)$ \\
\hline $\begin{array}{l}\text { cubic foot per second per } \\
\text { square mile } \\
{\left[\left(\mathrm{ft}^{3} / \mathrm{s}\right) / \mathrm{mi}^{2}\right]}\end{array}$ & 0.01093 & $\begin{array}{l}\text { cubic meter per } \\
\text { second per square } \\
\text { kilometer }\left[\left(\mathrm{m}^{3} / \mathrm{s}\right) / \mathrm{km}^{2}\right]\end{array}$ \\
\hline
\end{tabular}

OTHER ABBREVIATIONS

$\begin{array}{lrlr}\mathrm{BF} & \text { bank full } & \text { LWW } & \text { left wingwall } \\ \mathrm{cfs} & \text { cubic feet per second } & \text { MC } & \text { main channel } \\ \mathrm{D}_{50} & \text { median diameter of bed material } & \text { RAB } & \text { right abutment } \\ \mathrm{DS} & \text { downstream } & \text { RABUT } & \text { face of right abutment } \\ \mathrm{elev} & \text { elevation } & \text { RB } & \text { right bank } \\ \mathrm{f} / \mathrm{p} & \text { flood plain } & \text { ROB } & \text { right overbank } \\ \mathrm{ft} & \text { square feet } & \text { RWW } & \text { right wingwall } \\ \mathrm{ft} / \mathrm{ft} & \text { feet per foot } & \text { TH } & \text { town highway } \\ \mathrm{JCT} & \text { junction } & \text { UB } & \text { under bridge } \\ \mathrm{LAB} & \text { left abutment } & \text { US } & \text { upstream } \\ \mathrm{LABUT} & \text { face of left abutment } & \text { USGS } & \text { United States Geological Survey } \\ \text { LB } & \text { left bank } & \text { VTAOT Vermont Agency of Transportation } \\ \text { LOB } & \text { left overbank } & \text { WSPRO } & \text { water-surface profile model }\end{array}$

In this report, the words "right" and "left" refer to directions that would be reported by an observer facing downstream. Sea level: In this report, "sea level" refers to the National Geodetic Vertical Datum of 1929-- a geodetic datum derived from a general adjustment of the first-order level nets of the United States and Canada, formerly called Sea Level Datum of 1929.

In the appendices, the above abbreviations may be combined. For example, USLB would represent upstream left bank. 


\title{
LEVEL II SCOUR ANALYSIS FOR BRIDGE 46 (BRIDTH00050046) ON TOWN HIGHWAY 5, CROSSING NORTH BRANCH OTTAUQUECHEE RIVER, BRIDGEWATER, VERMONT
}

\author{
By Scott A. Olson and Donald L. Song
}

\section{INTRODUCTION AND SUMMARY OF RESULTS}

This report provides the results of a detailed Level II analysis of scour potential at structure BRIDTH00050046 on town highway 5 crossing the North Branch Ottauquechee River, Bridgewater, Vermont (figures 1-8). A Level II study is a basic engineering analysis of the site, including a quantitative analysis of stream stability and scour (U.S. Department of Transportation, 1993). A Level I study is included in Appendix E of this report. A Level I study provides a qualitative geomorphic characterization of the study site. Information on the bridge, gleaned from Vermont Agency of Transportation (VTAOT) files was compiled prior to conducting Level I and Level II analyses and can be found in Appendix D.

The site is in the Green Mountain physiographic province of central Vermont in the town of Bridgewater. The 5.61- $\mathrm{mi}^{2}$ drainage area is a predominantly rural and forested basin. In the vicinity of the study site, the banks are forested. Town highway 5 parallels the upstream left bank.

In the study area, the North Branch Ottauquechee River has a sinuous channel with a slope of approximately $0.015 \mathrm{ft} / \mathrm{ft}$, an average channel top width of $48 \mathrm{ft}$ and an average channel depth of $6 \mathrm{ft}$. The predominant channel bed materials are gravel and cobble with a median grain size $\left(\mathrm{D}_{50}\right)$ of $66.2 \mathrm{~mm}(0.217 \mathrm{ft})$. The geomorphic assessment at the time of the Level I and Level II site visit on November 2 and 3, 1994, indicated that the reach was stable.

The town highway 5 crossing of North Branch Ottauquechee River is a 40-ft-long, one-lane bridge consisting of a 34-ft steel-beam span, supported by vertical abutments with no wingwalls (Vermont Agency of Transportation, written communication, August 25, 1994). The left abutment is stone; the right abutment is log cribwork with type-2 stone fill (less than 36 inches diameter) along its base. Type- 2 stone fill has also been placed on the upstream and downstream sides of the road embankments, except the upstream left which has type-3 (less than 48 inches diameter). The channel is skewed approximately 60 degrees; the opening-skew-to-roadway is 30 degrees. Additional details describing conditions at the site are included in the Level II Summary, Appendix D, and Appendix E.

Scour depths and rock rip-rap sizes were computed using the general guidelines described in Hydraulic Engineering Circular 18 (Richardson and others, 1993). 
Total scour at a highway crossing is comprised of three components: 1) long-term degradation; 2) contraction scour (due to accelerated flow caused by a reduction in flow area at a bridge) and; 3) local scour (caused by accelerated flow around piers and abutments). Total scour is the sum of the three components. Equations are available to compute depths for contraction and local scour and a summary of these computed results follow.

Contraction scour for all modelled flows was $0.0 \mathrm{ft}$. Abutment scour ranged from $5.7 \mathrm{ft}$ to $7.7 \mathrm{ft}$. with the worst-case abutment scour occurring at the 500-year discharge. Additional information on scour depths and depths to armoring are included in the section titled "Scour Results". Scoured-streambed elevations, based on the calculated depths, are presented in tables 1 and 2. A cross-section of the computed scour at the bridge is presented in figure 8 . Scour depths were calculated assuming an infinite depth of erosive material and a homogeneous particle-size distribution.

It is generally accepted that the Froehlich equation (abutment scour) gives "excessively conservative estimates of scour depths" (Richardson and others, 1993, p. 22). Many factors, including historical performance during flood events, the geomorphic assessment, scour protection, and the results of the hydraulic analyses, must be considered to properly assess the validity of abutment scour results. Therefore, scour depths adopted by VTAOT may differ from the computed values documented herein, based on the consideration of additional contributing factors and experienced engineering judgement. 


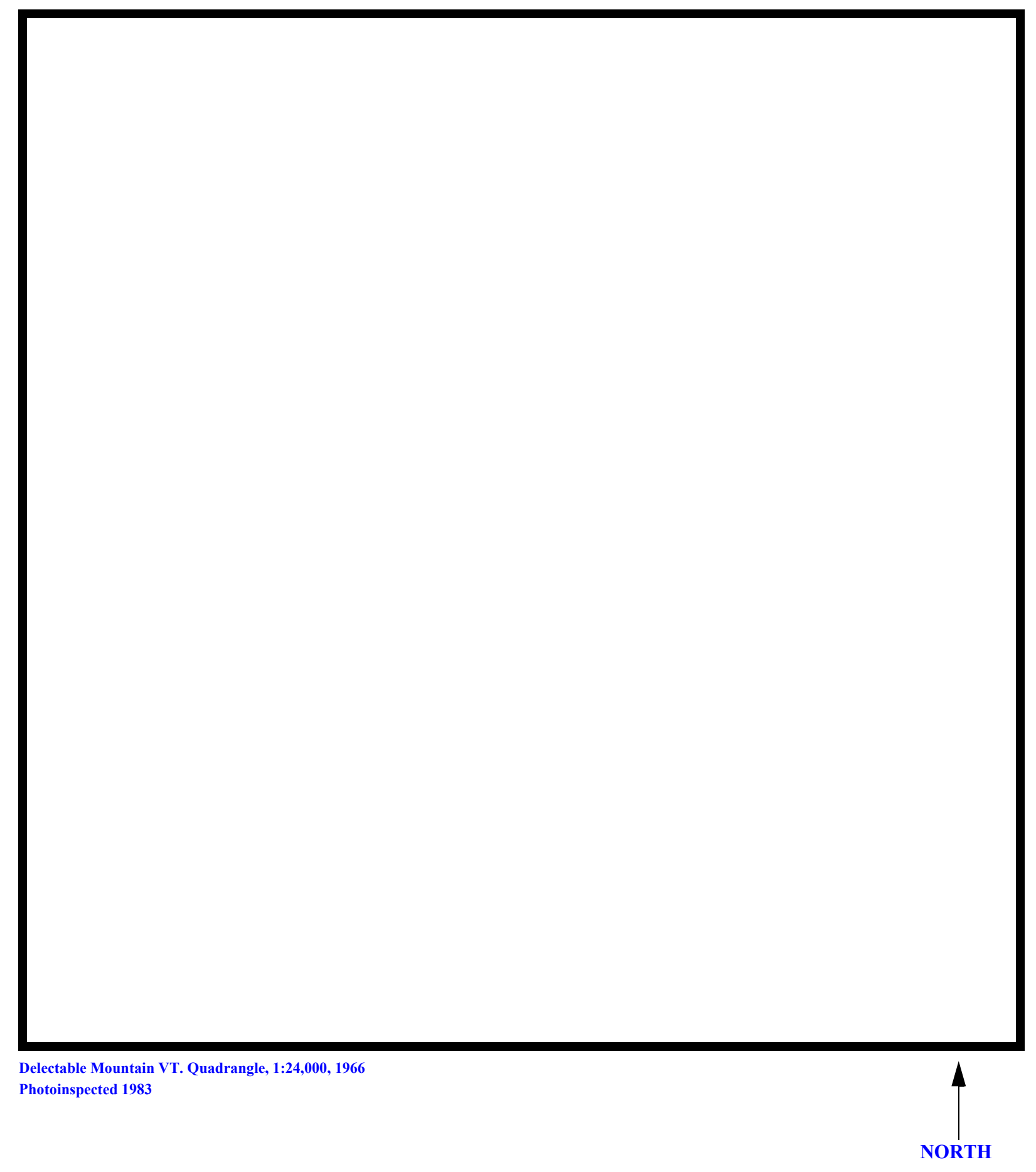

Figure 1. Location of study area on USGS 1:24,000 scale map. 
Figure 2. Location of study area on Vermont Agency of Transportation town highway map. 

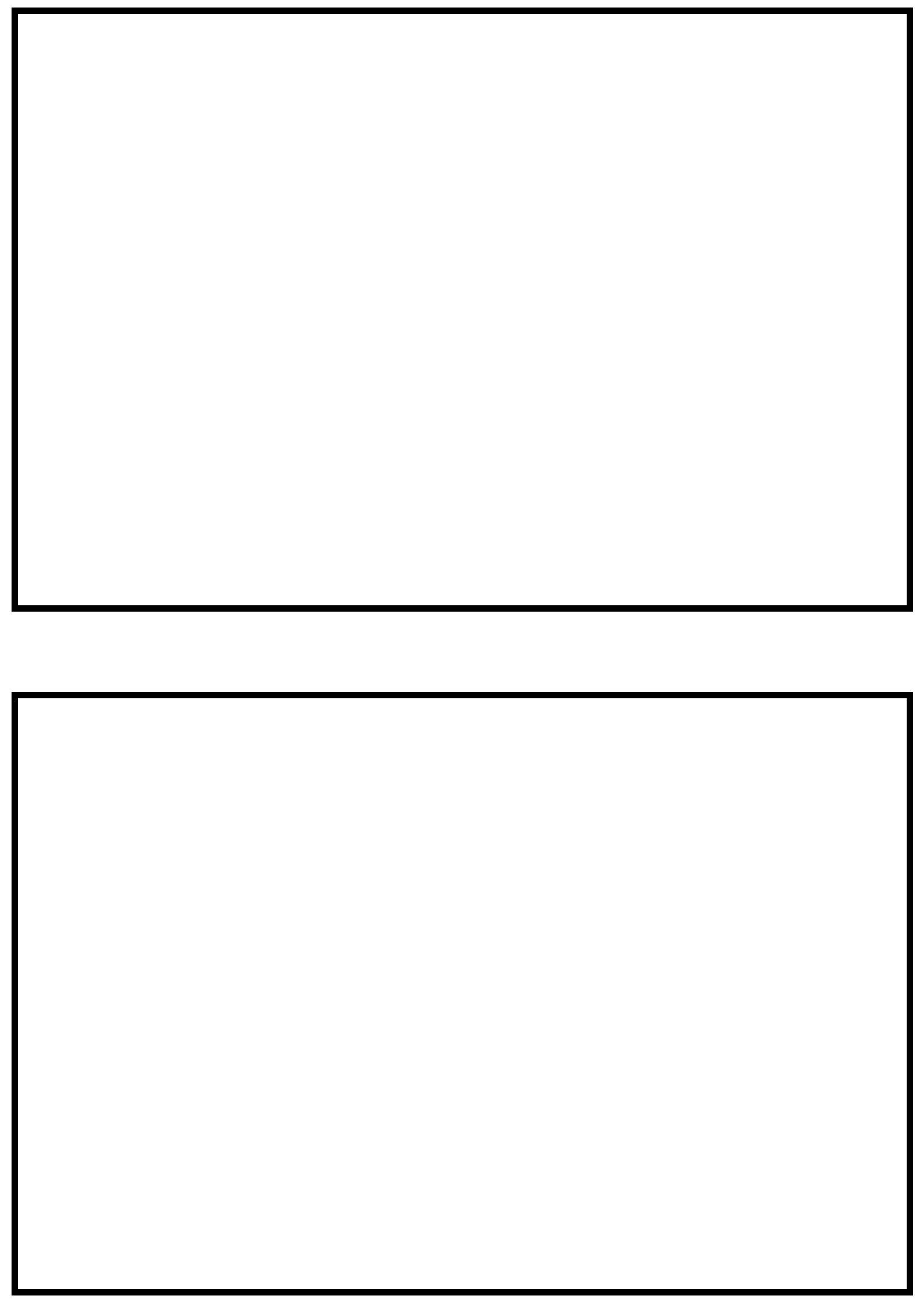

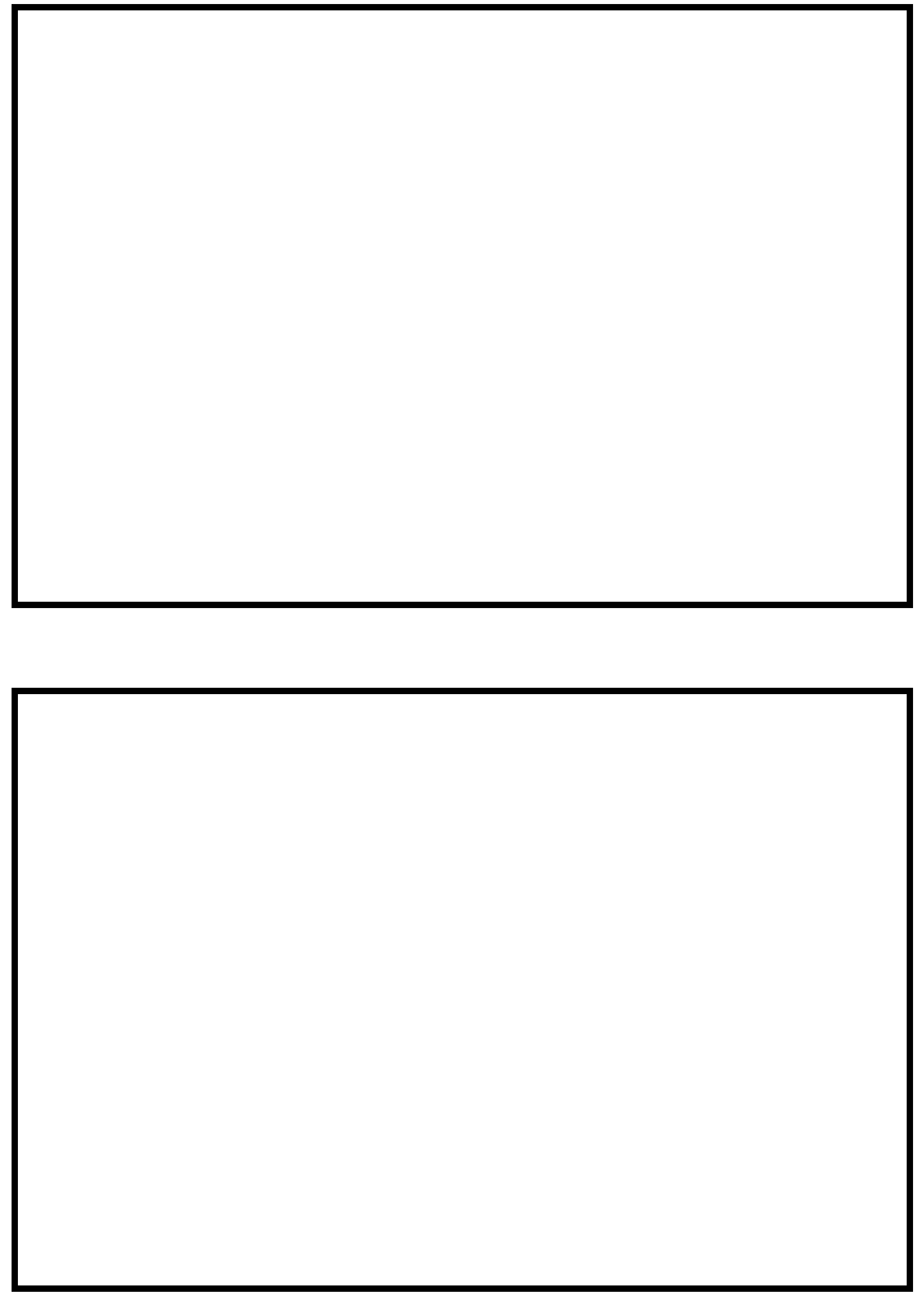


\section{LEVEL II SUMMARY}

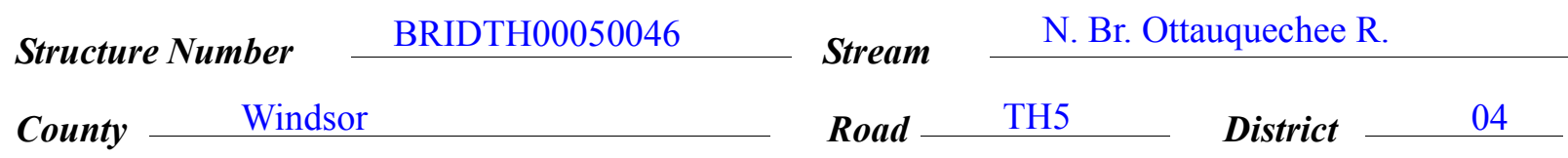

\section{Description of Bridge}

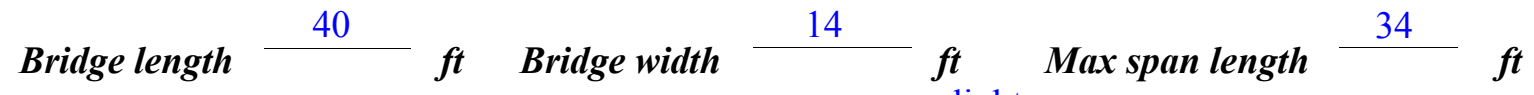
Alignment of bridge to road (on curve or straight)

\begin{tabular}{|c|c|c|c|}
\hline \multirow{2}{*}{ Abutment type } & 1 & \multirow{2}{*}{ Embankment type } & vertical \\
\hline & yes, right & & $11 / 2 / 94$ \\
\hline Stone fill on abutment? & Type-2 sto & $\begin{array}{l}\text { Dato of incnortion } \\
\mathrm{s} \text { along the right abutn }\end{array}$ & ent and at the road \\
\hline
\end{tabular}
embankments on the right upstream side and the left and right downstream sides. Type- 3 stone fill is on the left upstream road embankment.

The left abutment is laid-up stone. The right abutment is $\log$ cribbing with stone in gaps.

\section{$\mathrm{Y}$}

Is bridge skewed to flood flow according to Y Y survey? Angle

There is only a moderate bend to the channel at the bridge, however the bridge abutments are not aligned with the channel. Opening skew to roadway is 30 degrees.

Debris accumulation on bridge at time of Level I or Level II site visit:

\begin{tabular}{|c|c|c|c|}
\hline & $\begin{array}{c}\text { Date of insmortion } \\
11 / 02 / 94 \\
\end{array}$ & $\begin{array}{l}\text { Percent of alommal } \\
\text { blocked nortzontatly }\end{array}$ & $\begin{array}{l}\text { Percent of } 0 \text {. } \\
\text { blocked verticatty }\end{array}$ \\
\hline vel I & $11 / 03 / 94$ & - & - \\
\hline I וס, & Low & & \\
\hline
\end{tabular}

\section{Potential for debris}

November 2-3, 1994. The abutments are not aligned with the channel.

Doscriho anv, fonturos noar ar at tho hridoo that mav, affort flou, (includo ahsorvation dato) 


\section{Description of the Geomorphic Setting}

General topography The bridge is in a steep, narrow valley with moderate relief and little or no flood plains

Geomorphic conditions at bridge site: downstream (DS), upstream (US)

Date of inspection $\quad 11 / 02 / 94$

DS left: $\quad$ Steep valley wall

DS right: $\quad$ Moderate sloping channel bank to town highway 05 , then steep valley wall.

US left: $\quad$ Steep channel bank to town highway 05 , then steep valley wall.

US right: $\quad$ Steep valley wall.

\section{Description of the Channel}

\begin{tabular}{|c|c|c|c|}
\hline \multirow[b]{2}{*}{ Average top width } & & \multirow[b]{2}{*}{ Average depth } & 6 \\
\hline & $\stackrel{\boldsymbol{f t}}{\text { gravel and cobbles }}$ & & cobble-boulder \\
\hline Predominant bed material & & Bank material & arrow, incised \\
\hline channel with only slight sinuosity. & $\cdot \quad \cdots$ & .. $\quad$. & \\
\hline
\end{tabular}

$11 / 02 / 94$

Vegetative co 1 Forested

DS left: $\quad$ Forested

DS right: $\quad$ Forested

US left: $\quad$ Forested

US right: $\quad \underline{\mathrm{Y}}$

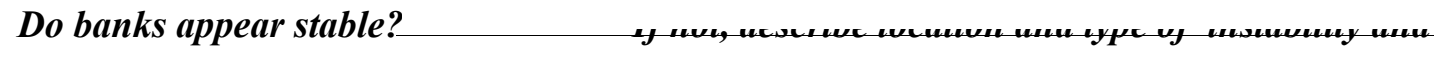

date of observatton.

11/2/94--None.

Describe any obstructions in channel and date of observation. 


\title{
Hydrology
}

Drainage area $\stackrel{5.61}{\boldsymbol{m i}^{2}}$

Percentage of drainage area in physiographic provinces: (approximate)

Physiographic province

Green Mountain Prov.
Percent of drainage area

100

\begin{abstract}
Is drainage area considered rural or urban?
Rural None.

urbanization:None.

Describe any significant
\end{abstract}

Is there a

\section{USGS gage description}

USGS gage number

Gage drainage area $\quad \mathrm{mi}^{2}$

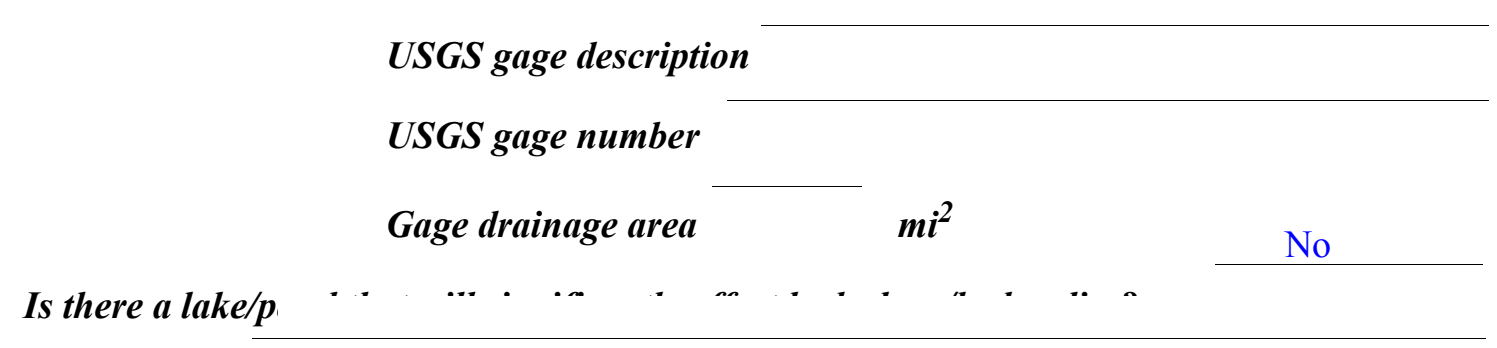

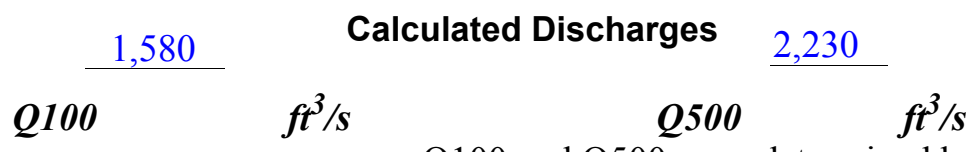

relationship [(5.6/5,0) to the 0.7 power] with flood frequency estimates at bridge 33 on the North Branch Ottauquechee River with a drainage area of 5.0 square miles. The Q100 discharge at bridge 33 (1460 cfs,) was available from VTAOT (VTAOT, written communtication, May 1995). The Q500 discharge at bridge 33 (2060 cfs) was based upon a weighted average of several empirical methods applicable for a drainage of this size in this region (Talbot, 1887; Potter, 1957a; Potter, 1957b; Johnson and Tasker, 1974; Federal Highway Administration, 1983; Richardson and others, 1983). 


\section{Description of the Water-Surface Profile Model (WSPRO) Analysis}

Datum for WSPRO analysis (USGS survey, sea level, VTAOT plans)

USGS survey

Datum tie between USGS survey and VTAOT plans $\quad$ Not applicable.

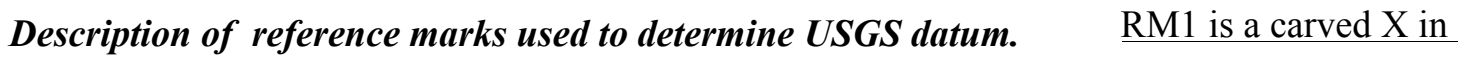

the top a wood deck plank at the upstream right corner of the bridge deck (elev. $4999.01 \mathrm{ft}$,

arbitrary datum). RM2 is a carved $\mathrm{X}$ in the top a wood deck plank at the downstream left corner

of the bridge deck (elev. $4999.41 \mathrm{ft}$, arbitrary datum).

\section{Cross-Sections Used in WSPRO Analysis}

\begin{tabular}{ccll}
\hline${ }^{1}$ Cross-section & $\begin{array}{c}\text { Section } \\
\text { Reference } \\
\text { Distance } \\
\text { (SRD) in feet }\end{array}$ & $\begin{array}{c}{ }^{2} \text { Cross-section } \\
\text { development }\end{array}$ & \multicolumn{1}{c}{ Comments } \\
\hline EXITX & -34 & 1 & $\begin{array}{l}\text { Exit section } \\
\text { Downstream Full-valley } \\
\text { section (Templated from } \\
\text { EXITX) }\end{array}$ \\
BRIDG & 0 & 2 & $\begin{array}{l}\text { Bridge section } \\
\text { RDWAY }\end{array}$ \\
APPRO & 7 & 1 & $\begin{array}{l}\text { Road Grade section } \\
\text { Modelled Approach sec- } \\
\text { tion (Templated from } \\
\text { APTEM) } \\
\text { APTEM }\end{array}$ \\
& 41 & 1 & $\begin{array}{l}\text { Approach section as sur- } \\
\text { veyed (Used as a tem- } \\
\text { plate) }\end{array}$ \\
\hline
\end{tabular}

${ }^{1}$ For location of cross-sections see plan-view sketch included with Level I field form, Appendix E. For more detail on how cross-sections were developed see WSPRO input file. 


\section{Data and Assumptions Used in WSPRO Model}

Hydraulic analyses of the reach were done by use of the Federal Highway Administration's WSPRO step-backwater computer program (Shearman and others, 1986, and Shearman, 1990). The analysis reported herein reflects conditions existing at the site at the time of the study. Furthermore, in the development of the model it was necessary to assume no accumulation of debris or ice at the site. Results of the hydraulic model are presented in the Bridge Hydraulic Summary, Appendix B, and figure 7.

Channel roughness factors (Manning's " $n$ ") used in the hydraulic model were estimated using field inspections at each cross section following the general guidelines described by Arcement, Jr. and Schneider (1989). Final adjustments to the values were made during the modelling of the reach. Channel " $\mathrm{n}$ " values for the reach ranged from 0.050 to 0.060 , and overbank " $n$ " values were 0.045 .

Normal depth at the exit section (EXITX) was assumed as the starting water surface. This depth was computed by use of the slope-conveyance method outlined in the User's manual for WSPRO (Shearman, 1990). The slope used was $0.0145 \mathrm{ft} / \mathrm{ft}$ which was determined from surveyed thalweg points downstream of the bridge.

The surveyed approach section (APTEM) was moved along the approach channel slope $(0.035 \mathrm{ft} / \mathrm{ft})$ to establish the modelled approach section (APPRO), one bridge length upstream of the upstream face as recommended by Shearman and others (1986). This approach also provides a consistent method for determining scour variables. 


\section{Bridge Hydraulics Summary}

Average bridge embankment elevation $\quad 4999.5 \quad f t$

Average low steel elevation

$4997.7 \quad f t$

100-year discharge $\quad 1,580 \quad \mathrm{ft}^{3} / \mathrm{s}$

Water-surface elevation in bridge opening $\quad 4997.9 f t$

Road overtopping? __ Y Discharge over road $72, \ldots$

Area of flow in bridge opening $\quad 174 \quad \mathrm{ft}^{2}$

Average velocity in bridge opening $\quad \begin{array}{lll}8.7 & f t / s\end{array}$

Maximum WSPRO tube velocity at bridge $10.1 \mathrm{ft} / \mathrm{s}$

Water-surface elevation at Approach section with bridge 4999.6

Water-surface elevation at Approach section without bridge $\quad \underline{4998.5}$

Amount of backwater caused by bridge

$1.1 \quad \boldsymbol{t}$

500-year discharge $\quad 2,230 \quad \mathrm{ft}^{3} / \mathrm{s}$

Water-surface elevation in bridge opening $\quad 4997.9 \mathrm{ft}$

Road overtopping? __ Y Discharge over road _ $782, \ldots$ s

Area of flow in bridge opening $\quad 174 \quad \mathrm{ft}^{2}$

Average velocity in bridge opening $\quad 8.3 \mathrm{ft} / \mathrm{s}$

Maximum WSPRO tube velocity at bridge $9.8 \ldots$ 's

Water-surface elevation at Approach section with bridge $\quad 5000.4$

Water-surface elevation at Approach section without bridge $\quad 4999,6$

Amount of backwater caused by bridge 0.8 .

Incipient overtopping discharge $\quad 1,470 \mathrm{ft}^{3} / \mathrm{s}$

Water-surface elevation in bridge opening 4997.2 it

Area of flow in bridge opening

$174 \boldsymbol{f t}^{2}$

Average velocity in bridge opening $\quad 9.1 \quad \mathrm{ft} / \mathrm{s}$

Maximum WSPRO tube velocity at bridge $11.3 \mathrm{ft} / \mathrm{s}$

Water-surface elevation at Approach section with bridge

Water-surface elevation at Approach section without bridge

4998.1

Amount of backwater caused by bridge N/A it

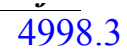




\section{Scour Analysis Summary}

\section{Special Conditions or Assumptions Made in Scour Analysis}

Scour depths were computed using the general guidelines described in Hydraulic Engineering Circular 18 (Richardson and others, 1993). Scour depths were calculated assuming an infinite depth of erosive material and a homogeneous particle-size distribution. The results of the scour analysis are presented in tables 1 and 2 and a graph of the scour depths is presented in figure 7.

The 100-year and 500-year discharges resulted in submerged orifice flow. Contraction scour at bridges with orifice flow is best estimated by use of the Chang pressureflow scour equation (oral communication, J. Sterling Jones, October 4, 1996). Therefore, contraction scour for these two discharges was computed by use of the Chang equation (Richardson and others, 1995, p. 145-146). Contraction scour was computed by use of the clear-water contraction scour equation (Richardson and others, 1993, p. 35, equations 18 and 19) for the incipient road over-flow discharge. The results of Laursen's clear-water contraction scour for the 100-year and 500-year events were also computed and can be found in appendix F. For contraction scour computations, the average depth in the contracted section (AREA/TOPWIDTH) is subtracted from the depth of flow computed by the scour equation (Y2) to determine the actual amount of scour.

Abutment scour was computed by the Froehlich equation (Richardson and others, 1993, p. 49, equation 24). Variables for the Froehlich equation include the Froude number of the flow approaching the embankments, the length of the embankment blocking flow, and the depth of flow approaching the embankment less any roadway overtopping.

The total scour depth computed at the right abutment for the 100-yr discharge was greater than that for the 500-yr discharge. Therefore, only the scour for the 100-year event is shown in figure 8 . The incipient overtopping model resulted in the worst-case total scour at the right abutment. 


\section{Scour Results}

100-yr discharge 500-yrdischarge

Incipient

Contraction scour:

(Scour depths in feet)

Main channel

Live-bed scour

Clear-water scour

Depth to armoring

Left overbank

Right overbank

Local scour:

Abutment scour

6.0

7.7

6.7

Left abutment

7.0

$5.7-$

7.6-

\section{Right abutment}

Pier scour

Pier 1

Pier 2

Pier 3

Abutments:

Left abutment

Right abutment

Piers:

Pier 1

Pier 2

\section{Riprap Sizing}

overtopping discharge 


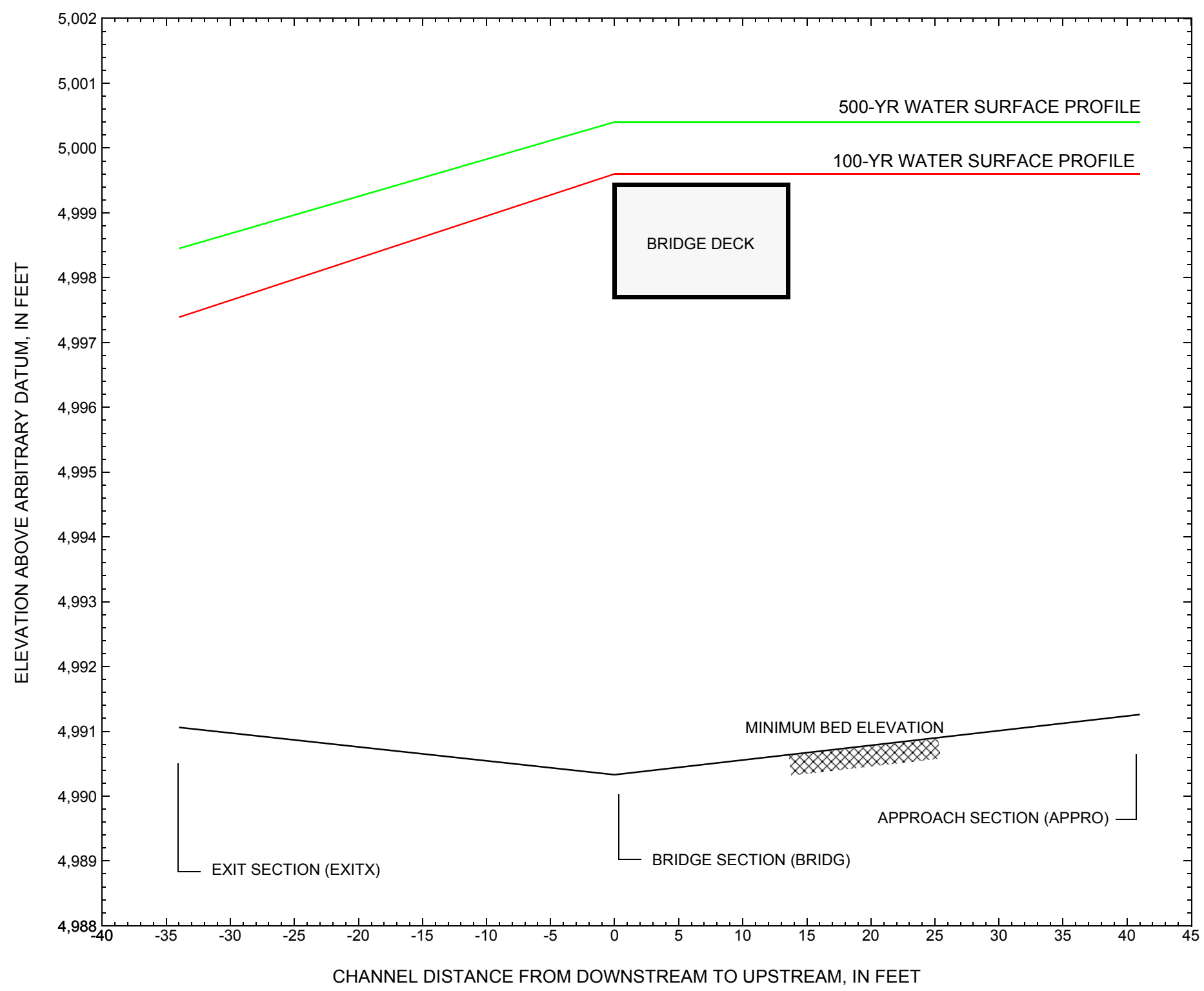

Figure 7. Water-surface profiles for the 100- and 500-yr discharges at structure BRIDTH00050046 on town highway 5, crossing the North Branch Ottauquechee River, Bridgewater, Vermont. 


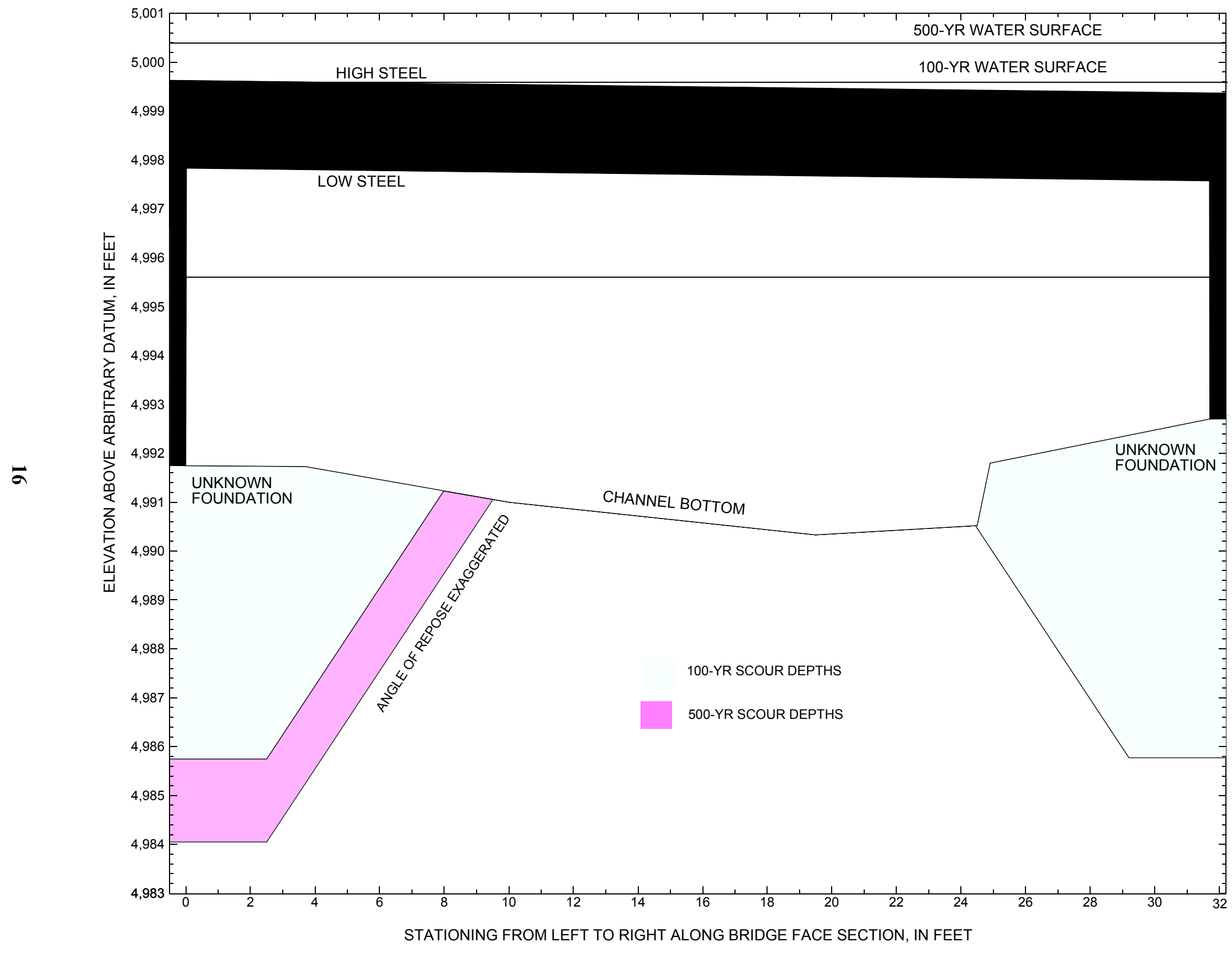

Figure 8. Scour elevations for the 100-yr and 500-yr discharges at structure BRIDTH00050046 on town highway 5, crossing the North Branch Ottauquechee River, Bridgewater, Vermont. 


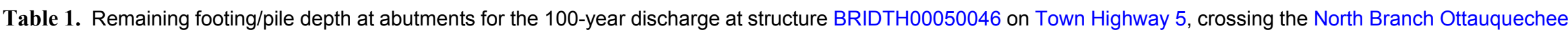
River, Bridgewater, Vermont.

[VTAOT, Vermont Agency of Transportation; --,no data]

\begin{tabular}{|c|c|c|c|c|c|c|c|c|c|c|c|}
\hline Description & Station $^{1}$ & $\begin{array}{l}\text { VTAOT } \\
\text { minimum } \\
\text { low-chord } \\
\text { elevation } \\
\text { (feet) }\end{array}$ & $\begin{array}{l}\text { Surveyed } \\
\text { minimum } \\
\text { low-chord } \\
\text { elevation }{ }^{2} \\
\text { (feet) }\end{array}$ & $\begin{array}{l}\text { Bottom of } \\
\text { footing } \\
\text { elevation } \\
\text { (feet) }\end{array}$ & $\begin{array}{c}\text { Channel } \\
\text { elevation at } \\
\text { abutment/ } \\
\text { pier }^{2} \\
\text { (feet) }\end{array}$ & $\begin{array}{l}\text { Contraction } \\
\text { scour depth } \\
\text { (feet) }\end{array}$ & $\begin{array}{l}\text { Abutment } \\
\text { scour } \\
\text { depth } \\
\text { (feet) }\end{array}$ & $\begin{array}{l}\text { Pier } \\
\text { scour } \\
\text { depth } \\
\text { (feet) }\end{array}$ & $\begin{array}{l}\text { Depth of } \\
\text { total scour } \\
\text { (feet) }\end{array}$ & $\begin{array}{c}\text { Elevation of } \\
\text { scour }^{2} \\
\text { (feet) }\end{array}$ & $\begin{array}{c}\text { Remaining } \\
\text { footing/pile } \\
\text { depth } \\
\text { (feet) }\end{array}$ \\
\hline \multicolumn{12}{|c|}{100 -yr. discharge is 1,580 cubic-feet per second } \\
\hline Left abutment & 0.0 & -- & 4997.9 & -- & 4991.8 & 0.0 & 6.0 & -- & 6.0 & 4985.8 & -- \\
\hline Right abutment & 31.7 & -- & 4997.4 & -- & 4992.8 & 0.0 & 7.0 & -- & 7.0 & 4985.8 & -- \\
\hline
\end{tabular}

1. Measured along the face of the most constricting side of the bridge.

2. Arbitrary datum for this study.

Table 2. Remaining footing/pile depth at abutments for the 500-year discharge at structure BRIDTH00050046 on Town Highway 5, crossing the North Branch Ottauquechee River, Bridgewater, Vermont.

[VTAOT, Vermont Agency of Transportation; --, no data]

\begin{tabular}{|c|c|c|c|c|c|c|c|c|c|c|c|}
\hline Description & Station ${ }^{1}$ & $\begin{array}{l}\text { VTAOT } \\
\text { minimum } \\
\text { low-chord } \\
\text { elevation } \\
\text { (feet) }\end{array}$ & $\begin{array}{l}\text { Surveyed } \\
\text { minimum } \\
\text { low-chord } \\
\text { elevation } \\
\text { (feet) }\end{array}$ & $\begin{array}{c}\text { Bottom of } \\
\text { footing } \\
\text { elevation } \\
\text { (feet) }\end{array}$ & $\begin{array}{c}\text { Channel } \\
\text { elevation at } \\
\text { abutment/ } \\
\text { pier }^{2} \\
\text { (feet) }\end{array}$ & $\begin{array}{l}\text { Contraction } \\
\text { scour depth } \\
\text { (feet) }\end{array}$ & $\begin{array}{l}\text { Abutment } \\
\text { scour } \\
\text { depth } \\
\text { (feet) }\end{array}$ & $\begin{array}{l}\text { Pier } \\
\text { scour } \\
\text { depth } \\
\text { (feet) }\end{array}$ & $\begin{array}{l}\text { Depth of } \\
\text { total scour } \\
\text { (feet) }\end{array}$ & $\begin{array}{c}\text { Elevation of } \\
\text { scour }^{2} \\
\text { (feet) }\end{array}$ & $\begin{array}{c}\text { Remaining } \\
\text { footing/pile } \\
\text { depth } \\
\text { (feet) }\end{array}$ \\
\hline \multicolumn{12}{|c|}{500 -yr. discharge is 2,230 cubic-feet per second } \\
\hline Left abutment & 0.0 & -- & 4997.9 & -- & 4991.8 & 0.0 & 7.7 & -- & 7.7 & 4984.1 & -- \\
\hline Right abutment & 31.7 & -- & 4997.4 & -- & 4992.8 & 0.0 & 5.7 & -- & 5.7 & 4987.1 & -- \\
\hline
\end{tabular}

1. Measured along the face of the most constricting side of the bridge.

2. Arbitrary datum for this study. 


\section{SELECTED REFERENCES}

Arcement, G.J., Jr., and Schneider, V.R., 1989, Guide for selecting Manning's roughness coefficients for natural channels and flood plains: U.S. Geological Survey Water-Supply Paper 2339, 38 p.

Barnes, H.H., Jr., 1967, Roughness characteristics of natural channels: U.S. Geological Survey Water-Supply Paper 1849,213 p.

Brown, S.A. and Clyde, E.S., 1989, Design of riprap revetment: Federal Highway Administration Hydraulic Engineering Circular No. 11, Publication FHWA-IP-89-016, 156 p.

Federal Highway Administration, 1983, Runoff estimates for small watersheds and development of sound design: Federal Highway Administration Report FHWA-RD-77-158

Federal Emergency Management Agency, 1980, Flood Insurance Study, Town of Bridgewater, Windsor County, Vermont: Washington, D.C., January 1980.

Froehlich, D.C., 1989, Local scour at bridge abutments in Ports, M.A., ed., Hydraulic Engineering--Proceedings of the 1989 National Conference on Hydraulic Engineering: New York, American Society of Civil Engineers, p. 13-18.

Hayes, D.C.,1993, Site selection and collection of bridge-scour data in Delaware, Maryland, and Virginia: U.S. Geological Survey WaterResources Investigation Report 93-4017, 23 p.

Interagency Advisory Committee on Water Data, 1982, Guidelines for determining flood flow frequency: U.S. Geological Survey, Bulletin 17B of the Hydrology Subcommittee, 190 p.

Johnson, C.G. and Tasker, G.D.,1974, Progress report on flood magnitude and frequency of Vermont streams: U.S. Geological Survey OpenFile Report 74-130, 37 p.

Lagasse, P.F., Schall, J.D., Johnson, F., Richardson, E.V., Richardson, J.R., Chang, F., 1991, Stream Stability at Highway Structures: Federal Highway Administration Hydraulic Engineering Circular No. 20, Publication FHWA-IP-90-014, 195 p.

Laursen, E.M., 1960, Scour at bridge crossings: Journal of the Hydraulics Division, American Society of Civil Engineers, v. 86, no. HY2, p. $39-53$.

Potter, W. D., 1957a, Peak rates of runoff in the Adirondack, White Mountains, and Maine woods area, Bureau of Public Roads

Potter, W. D., 1957b, Peak rates of runoff in the New England Hill and Lowland area, Bureau of Public Roads

Richardson, E.V. and Davis, S.R., 1995, Evaluating scour at bridges: Federal Highway Administration Hydraulic Engineering Circular No. 18, Publication FHWA-IP-90-017, 204 p.

Richardson, E.V., Harrison, L.J., Richardson, J.R., and Davis, S.R., 1993, Evaluating scour at bridges: Federal Highway Administration Hydraulic Engineering Circular No. 18, Publication FHWA-IP-90-017, 131 p.

Richardson, E.V., Simons, D.B., and Julien, P.Y., 1990, Highways in the river environment: Federal Highway Administration Publication FHWA-HI-90-016.

Ritter, D.F., 1984, Process Geomorphology: W.C. Brown Co., Debuque, Iowa, 603 p.

Shearman, J.O., 1990, User's manual for WSPRO--a computer model for water surface profile computations: Federal Highway Administration Publication FHWA-IP-89-027, 187 p.

Shearman, J.O., Kirby, W.H., Schneider, V.R., and Flippo, H.N., 1986, Bridge waterways analysis model; research report: Federal Highway Administration Publication FHWA-RD-86-108, 112 p.

Talbot, A.N., 1887, The determination of water-way for bridges and culverts.

U.S. Department of Transportation, 1993, Stream stability and scour at highway bridges, Participant Workbook: Federal Highway Administration Publication FHWA HI-91-011.

U.S. Geological Survey, 1966, Delectable Mountain, Vermont 7.5 Minute Series quadrangle map: U.S. Geological Survey Topographic Maps, Photoinspected 1983, Scale 1:24,000. 


\section{APPENDIX A: \\ WSPRO INPUT FILE}




\section{WSPRO INPUT FILE}

$\mathrm{XS}$

GR

GR

GR

GR

$\mathrm{N}$

SA

XS

*

$\mathrm{BR}$

GR

GR

GR

$\mathrm{N}$

CD

*

XR

GR

GR

GR

GR

$\mathrm{BP}$

*

GR

GR

GR

GR

AS

GT

$\mathrm{N}$

SA

*

HP 1 BRIDG

HP 2 BRIDG

HP 1 APPRO

HP 2 APPRO

HP 1 BRIDG

HP 2 BRIDG

HP 2 RDWAY

HP 1 APPRO

U.S. GEOLOGICAL SURVEY WSPRO INPUT FILE brid046.wsp CREATED ON 31-AUG-95 FOR BRIDGE BRIDTH00050046 USING FILE brid046.dca HYDRAULIC ANALYSIS OF BRID046 SAO

* $* 0.002$

$\begin{array}{lllllllllllllllllllll}6 & 29 & 30 & 552 & 553 & 551 & 5 & 16 & 17 & 13 & 3 & * & 15 & 14 & 23 & 21 & 11 & 12 & 4 & 7 & 3\end{array}$

Incipient overflow discharge requires different model input at the approach section because if the left overbank is overtopped then the roadway WILL be overtopped. Thus, for incipient overtopping model station 0.0 was used as a control point. 15802230

0.01450 .0145

$\operatorname{EXITX} \quad-34$

$-57.0,5006.66$

$-15.3,4996.22$

$9.0,4991.27$

$3.3,4991.37$

$40.3,4997.25$

$109.3,5000.90$

0.060

$53.9,4999.35$

$127.0,5010.56$

54.

$0 * \star \star 0.021$

$\begin{array}{lll}0 & 4997.7 \quad 30\end{array}$

$0.0,4997.92$

$19.5,4990.33$

$31.7,4997.41$

0.050

113.5

$\begin{array}{lll}7 & 14.0 & 2\end{array}$

$-104.6,5011.00$

$-45.3,4998.56$

$39.9,4999.29$

$-84.0,5004.90$

$-31.5,4999.02$

$-69.6,5003.79$

$-14.6,4999.79$

$61.3,4999.61$

$97.5,4999.77$

$160.8,5010.56$

0

0

66

$-90.3,5011.00$

$-69.7,5004.90$

$-55.3,5003.79$

$0.0,4999.31$

$-42.8,5001.43$

$-31.0,4998.56$

$-17.2,4999.02$

$21.5,4992.23$

$50.1,5001.02$

$-57.1,5001.43$

$0.0,4999.71$

$111.4,4999.27$

$12.7,4992.53$

$16.9,4992.13$

$10.0,4991.00$

$31.2,4992.77$

$30.5,4994.12$

$40.5,4999.79$

$10.1,4992.85$

$24.8,4992.77$

$54.3,5004.69$

$50.1,5001.02$

The 0 on the GT record below is for the INCIPIENT OVERFLOW MODEL ONLY 41

$-0.870$

0.045

0.060

0

4997.2014997 .20

$4997.20 * * 1470$

4998.0914998 .09

4998.09 * * 1470

4997.8914997 .89

$4997.89 *$ * 1510

$4999.60 * * 72$

4999.6014999 .60 


\section{APPENDIX B: \\ WSPRO OUTPUT FILE}


U.S. GEOLOGICAL SURVEY WSPRO INPUT FILE brid046.wsp

CREATED ON 31-AUG-95 FOR BRIDGE BRIDTH00050046 USING FILE brid046.dca HYDRAULIC ANALYSIS OF BRID046 SAO

$$
\text { *** RUN DATE \& TIME: 01-19-96 15:36 }
$$

\begin{tabular}{|c|c|c|c|c|c|c|c|c|c|}
\hline \multirow{3}{*}{$\begin{array}{c}\text { CROSS-SECTI } \\
\text { WSEL }\end{array}$} & $\mathrm{N} \quad \mathrm{PI}$ & RTIES: & ISEQ & $3 ;$ & $I D=B$ & BRIDG ; & $\mathrm{SRD}=$ & & \\
\hline & SA\# & AREA & I & TOPW & WETP & ALPH & LEW & REW & QCR \\
\hline & 1 & 174. & 10043 & 2 . & 64. & & & & 10282 \\
\hline 4997.89 & & 174. & 10043 & 2 . & 64. & 1.00 & 0. & 32. & 10282 \\
\hline
\end{tabular}

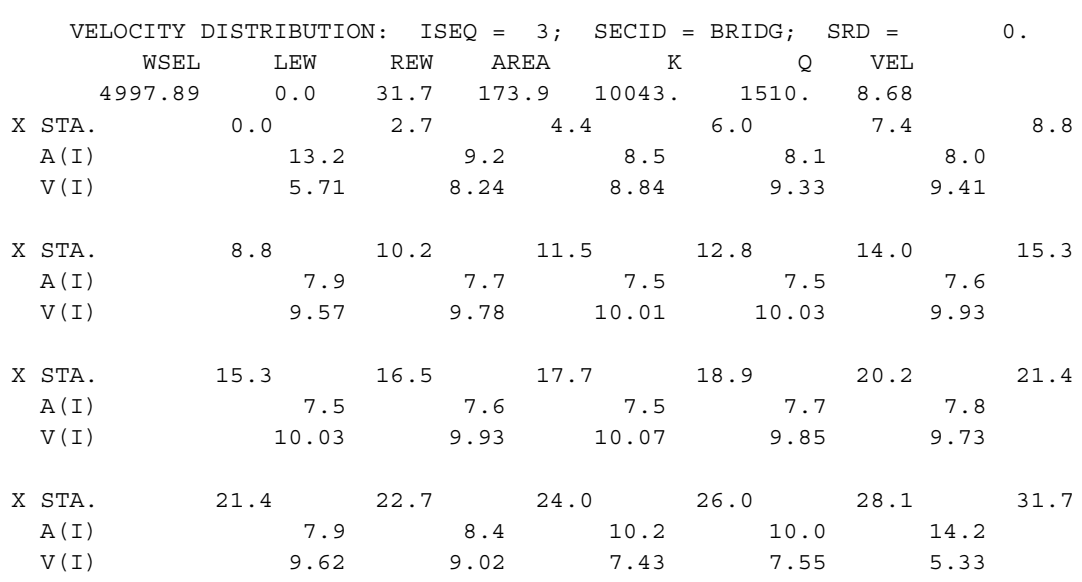

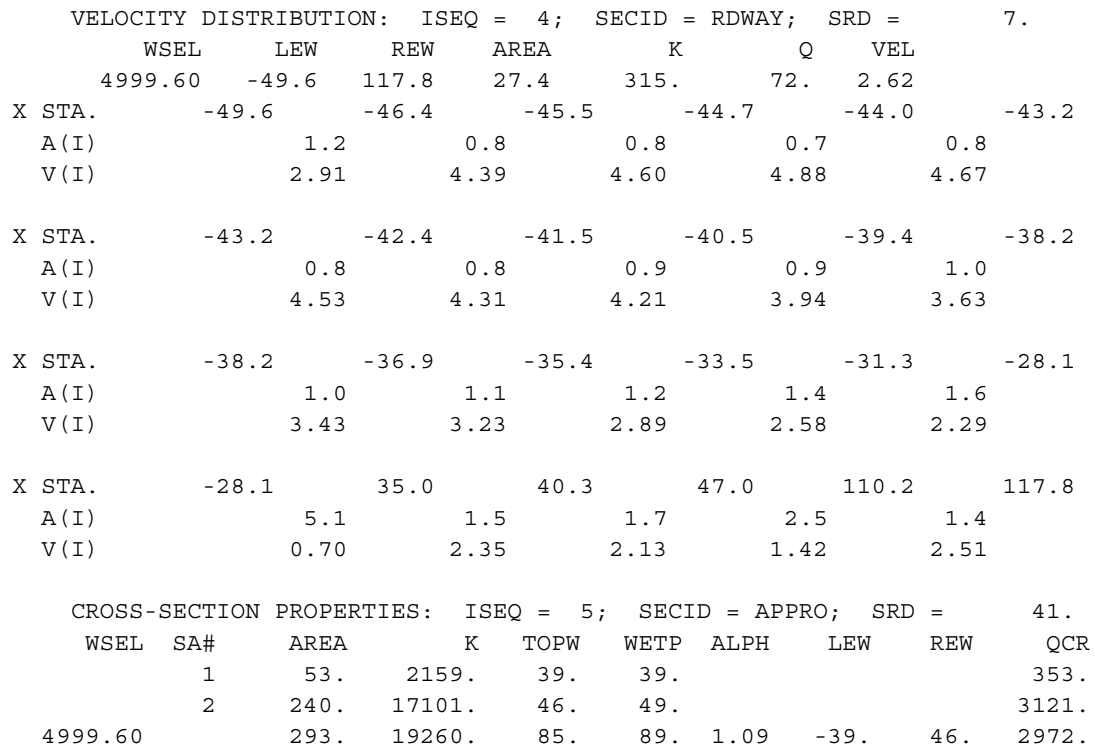

VELOCITY DISTRIBUTION $:$ ISEQ $=5 ; \quad$ SECID $=$ APPRO $; \quad$ SRD $=41$.

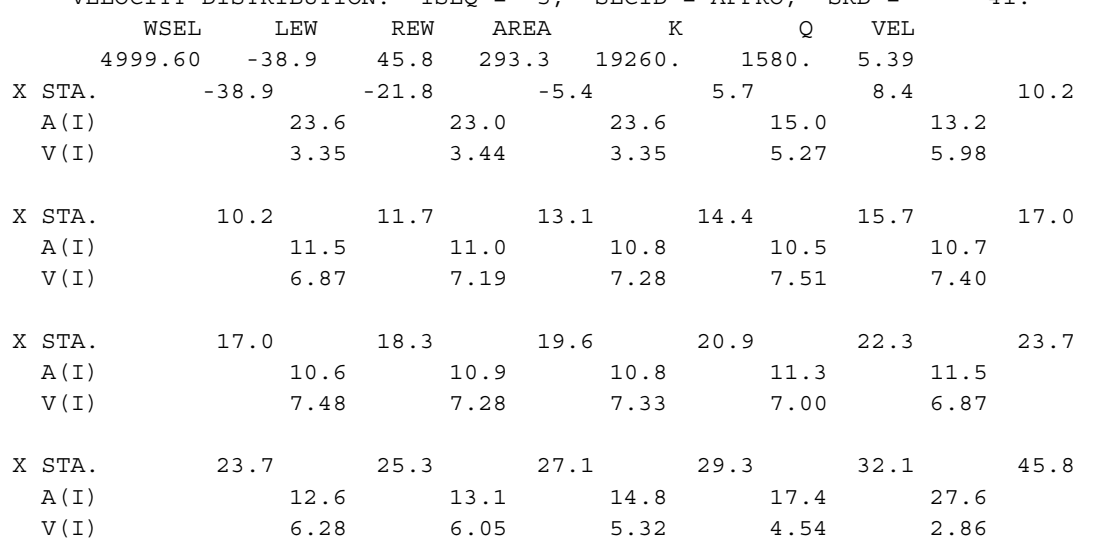


WSPRO OUTPUT FILE (continued)

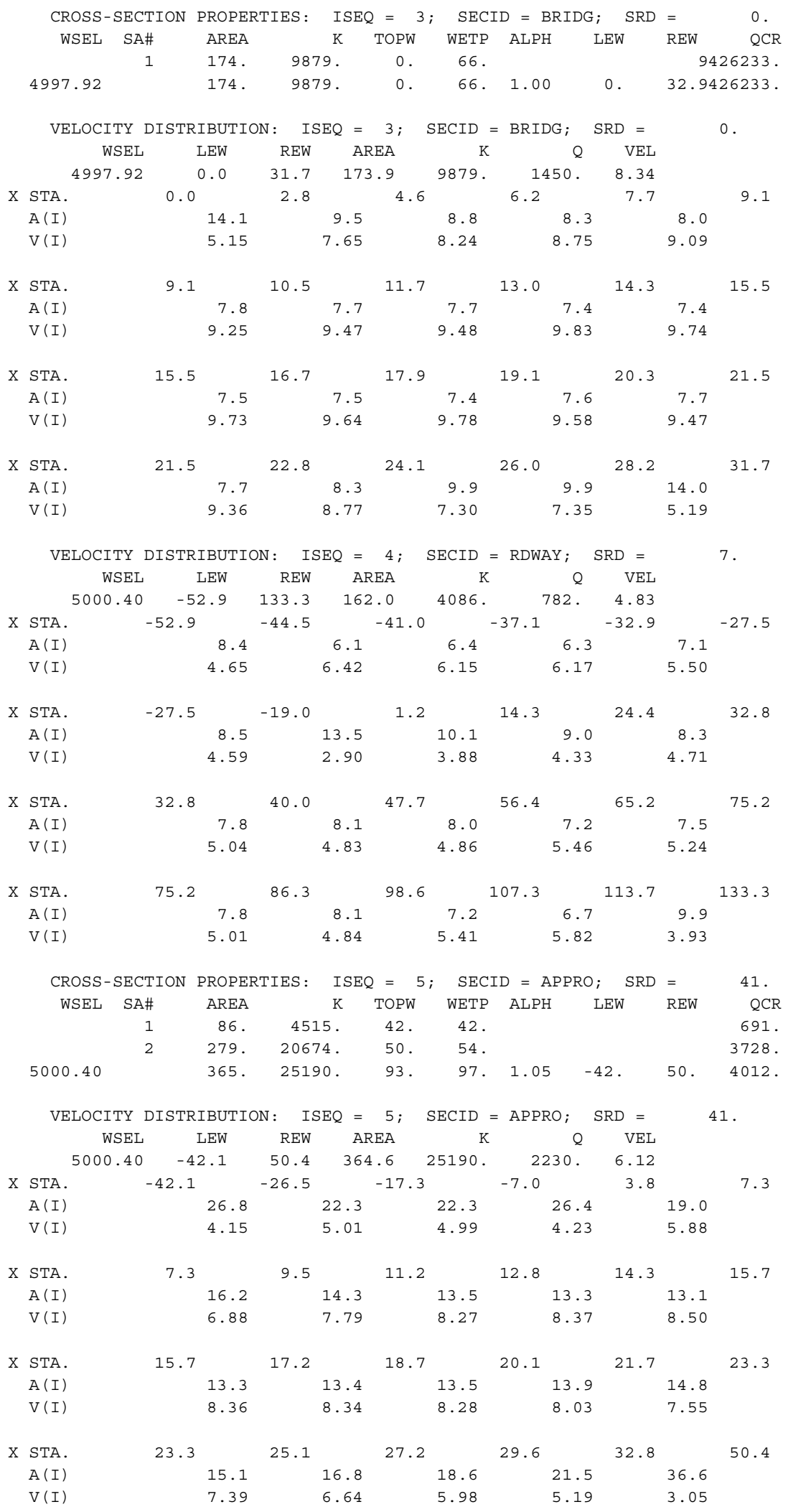


WSPRO OUTPUT FILE (continued)

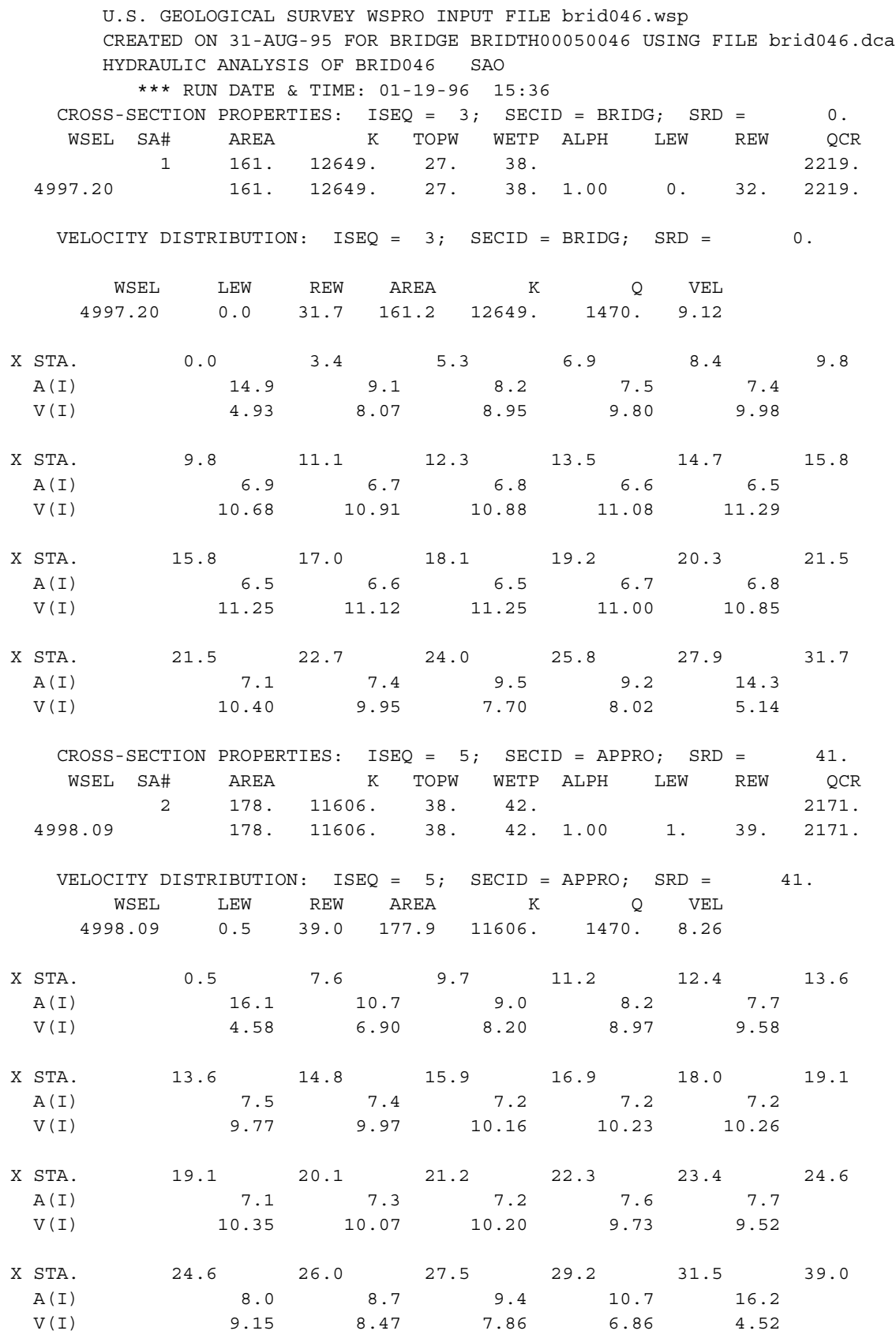


WSPRO OUTPUT FILE (continued)

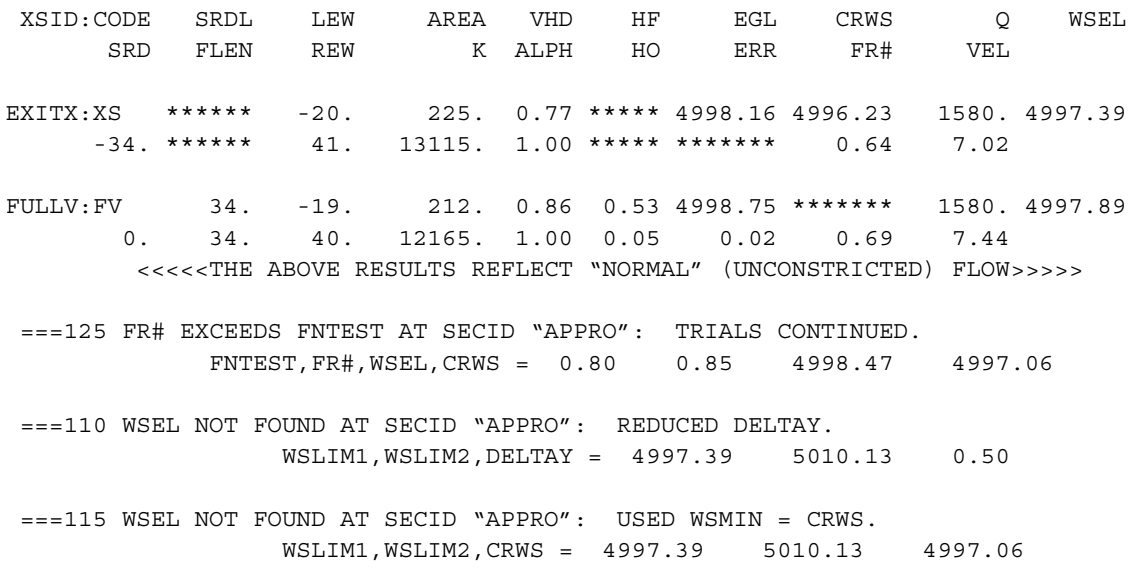


WSPRO OUTPUT FILE (continued)

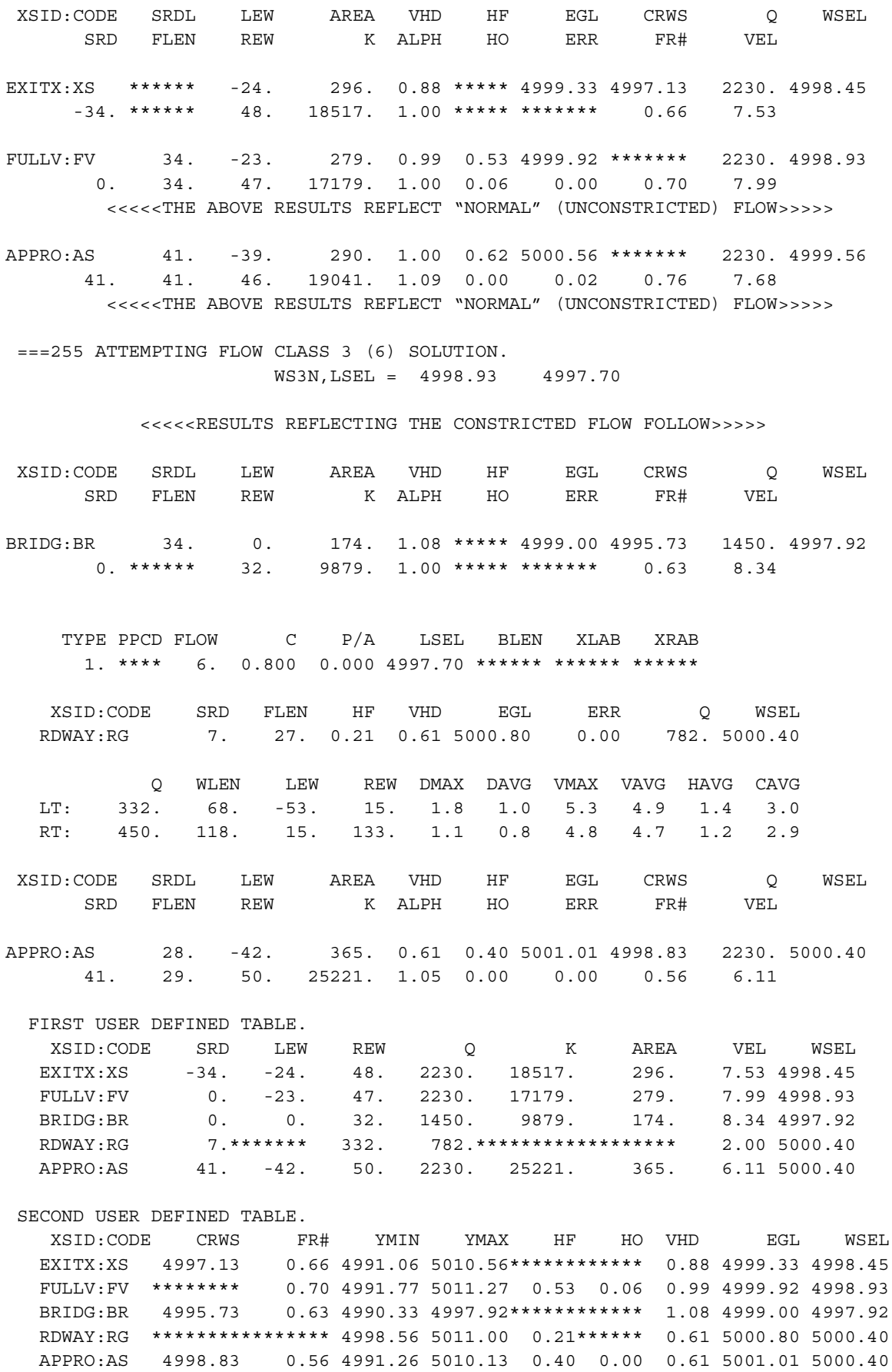


WSPRO OUTPUT FILE (continued)

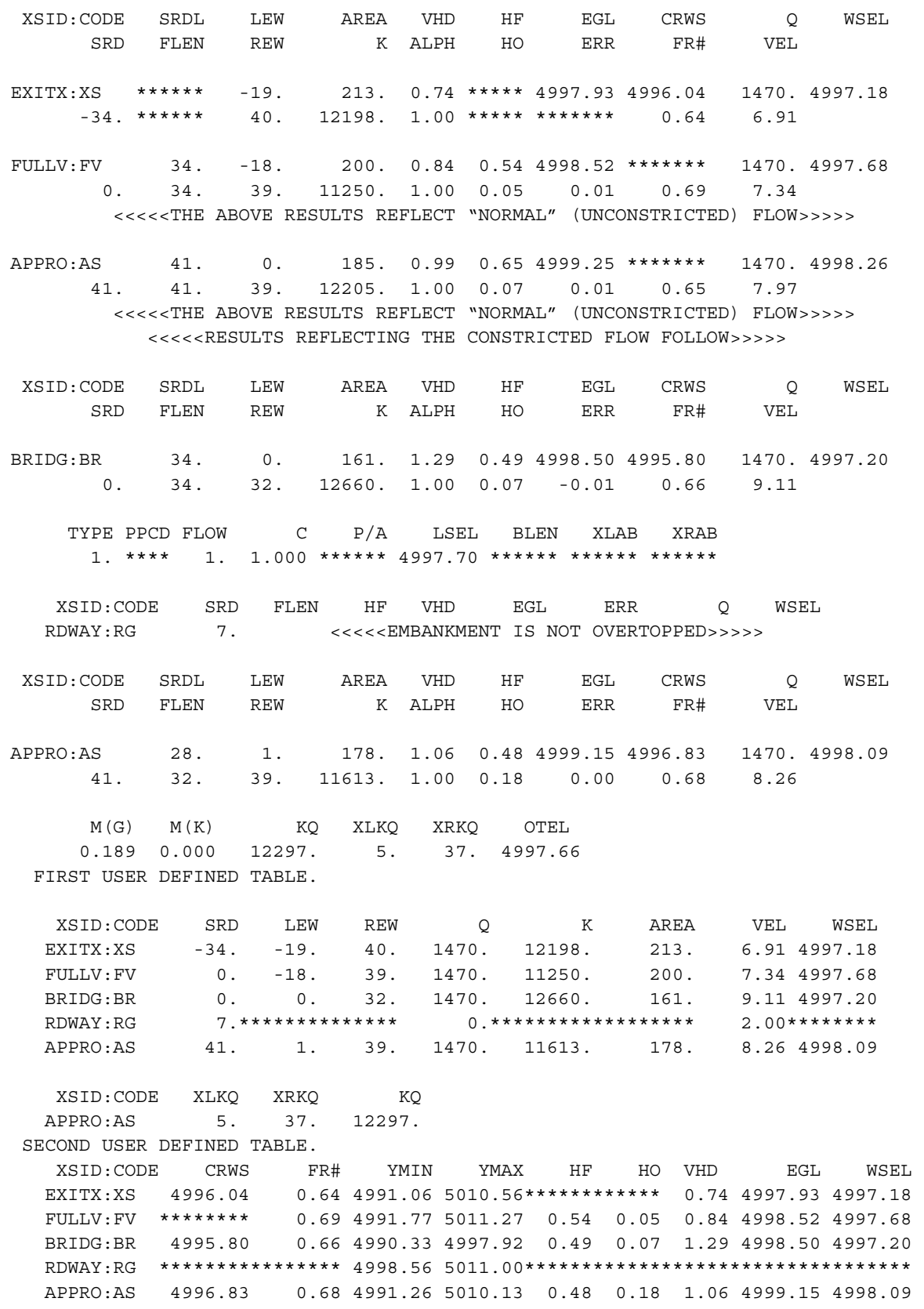




\section{APPENDIX C:}

\section{BED-MATERIAL PARTICAL-SIZE DISTRIBUTION}




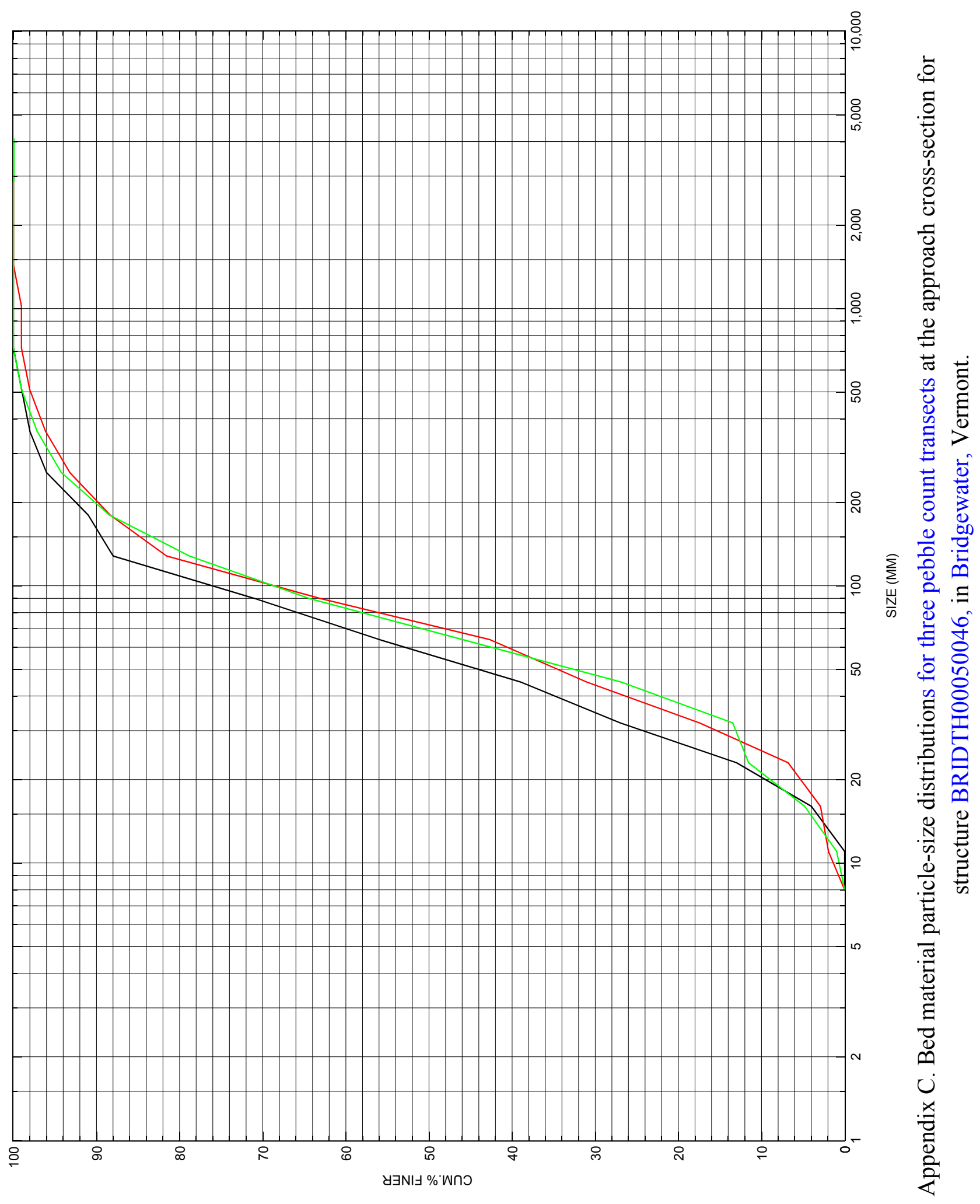




\section{APPENDIX D: \\ HISTORICAL DATA FORM}

